\title{
ANALIZA WPLYWU POWIERZCHNI PRZEGRÓD PRZEZROCZYSTYCH NA MIKROKLIMAT PASYWNEGO BUDYNKU UŻYTECZNOŚCI PUBLICZNEJ
}

\begin{abstract}
Publikacja zawiera informacje dotyczące wpływu powierzchni przegród przezroczystych na mikroklimat budynku pasywnego. Przeprowadzono pięć symulacji pozwalających na określenie $\mathrm{w}$ jakim stopniu rozkład stolarki okiennej jest w stanie zmienić warunki środowiskowe we wnętrzu, wybranego z całego obiektu, pomieszczenia do analizy i wpłynąć na ograniczenie przegrzewania latem. Usuwano o 50\% i $100 \%$ powierzchni okna na elewacji południowej i północnej. W symulacjach nie uwzględniano innych możliwości związanych $\mathrm{z}$ minimalizacją nadmiernych zysków solarnych takich jak rodzaj zastosowanych osłon przeciwsłonecznych, nocne przewietrzanie, wpływ masy termicznej czy też kontrola wilgotności i ruchu powietrza. W związku $\mathrm{z}$ wąskim zakresem analizy, rozbieżności w wynikach są niewielkie, pozwalają jednak na sformułowanie wstępnych wniosków. Południowe elewacje szklone przede wszystkim wpływają na wartości temeperatury powietrza wewnetrznego i wskaźnik przewidywanej oceny średniej. Wariant, w którym zredukowano powierzchnie transparentne na elewacji południowej o 100\% wykazał najmniejszą wartość wskażnika przewidywanej oceny średniej. Duże ilości promieniowania słonecznego, przenikającego przez spore powierzchnie transparentne po stronie południowej, są powodem dyskomfortu. Okna północne w mniejszym stopniu przyczyniają się do obniżenia zysków solarnych, w porównaniu z południowymi. Projektowanie przeszklenia nie może być przesadzone w żadną ze stron. Zbyt duże powierzchnie przeszklone mogą być nie tylko powodem strat ciepła w zimie, ale też przyczyną przegrzewania latem. Zapewnienie właściwego mikroklimatu w danym środowisku gwarantuje efektywność wykonywanych zadań i zdrowie użytkowników dlatego powinno być kluczową kwestią w projektowaniu.
\end{abstract}

Słowa kluczowe: komfort cieplny, PMV, przegrzewanie, przeszklenia

\section{Wprowadzenie}

Dążąc do zapewnienia komfortu cieplnego w budynku, poszukuje się uzasadnionych ekonomicznie, różnych rozwiązań konstrukcyjnych. Wielkość

\footnotetext{
${ }^{1}$ Anna Dudzińska, Instytut Materiałów i Konstrukcji Budowlanych, Zakład Budownictwa i Fizyki Budowli, Wydział Inżynierii Lądowej, Politechnika Krakowska
} 
oraz rozmieszczenie przegród przezroczystych jest jednym z elementów kształtujących mikroklimat wnętrza. Przenikające przez powierzchnie przezroczyste promieniowanie słoneczne jest źródłem zysków ciepła, wpływających na dyskomfort użytkowników. W sezonie grzewczym zyski od promienowania są jak najbardziej pożądane i uwzględniane na etapie projektowania budynków pasywnych. W sezonie letnim zyski te stają się poważnym utrudnieniem, prowadzącym często do przegrzewania pomieszczeń.

Wymagania dotyczące izolacyjnoście cieplnej okien zostały określone w rozporządzeniu Ministra Infrastruktury w sprawie warunków technicznych, jakim powinny odpowiadać budynki i ich usytuowanie [1]. Określenie współczynnika przenikania ciepła dla powierzchni przezroczystych nie odzwierciedla rzeczywistych ilości ciepła, przenikającego przez przegrodę. Istotne jest racjonalne ulokowanie okien $\mathrm{w}$ zależności od usytuowania przegrody względem strony swiata.

\section{Charakterystyka modelu hali sportowej}

Poddana analizie hala sportowa w Słomnikach jest istniejącym obiektem, którego powierzchnie szklone skierowane są $\mathrm{w}$ kierunku północnym oraz południowym. Na elewacji południowej znajduje się największy procent przeszklenia i tam też generowane są najwyższe zyski słoneczne. Budynek spełnia wymagania warunków technicznych $\mathrm{w}$ kwestii stosunku powierzchni okien do powierzchni podłogi oraz współczynnika redukcji promieniowania $\mathrm{f}_{\mathrm{c}}$.

Procentowy stosunek powierzchni przeszklonych w konfrontacji z usytuowaniem względem stron świata zobrazowano na rysunku 1.

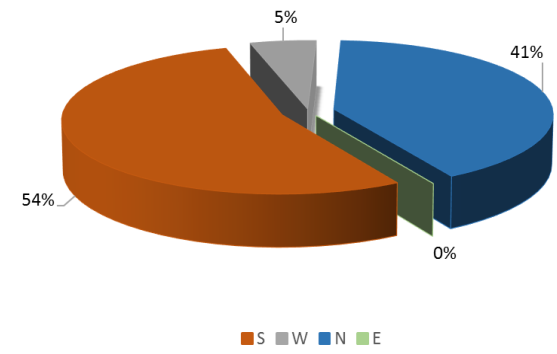

Rys. 1. Procentowy udział poszczególnych orientacji przeszklenia w hali

Fig. 1. Percentage orientation glazing in the hall

Powierzchnia użytkowa bydunku wynosi ok $1755 \mathrm{~m}^{2}$, a powierzchnie okien zajmują $213,77 \mathrm{~m}^{2}$. Hala spełnia wymagania stawiane przegrodom przezroczystym, zawarte $\mathrm{w} \S 57$ rozporządzenia w sprawie warunków technicznych, jakim powinny odpowiadać budynki i ich usytuowanie [1]. W analizach nie uwzględniono wpływu redukcji okien poszczególnych elewacji na wymogi warunków technicznych. 
W celu określenia wielkości wpływu przeszklenia na mikroklimat w budynku, wykonano ciąg symulacji, w których usuwano odpowiednio okna na elewacji południowej i północnej. Pozwoliło to na analizę wskaźnika przewidywanej oceny średniej PMV jako miary komfortu cieplnego w zależności od umiejscowienia i ilości przegród przezroczystych.

Okna hali szklone są potrójną szybą o współczynniku przenikania ciepła $\mathrm{U}=0,79 \mathrm{~W} / \mathrm{m}^{2} \mathrm{~K}$. Współczynnik całkowitej przepuszczalności promieniowania SHGC - Solar Heat Gain Coefficient ma wartość 0,49.

Przeprowadzono pięć symulacji:

- podstawowa - zgodna z założeniami projektu;

- usunięcie 50\% przeszklenia elewacji południowej areny sportowej;

- usunięcie $100 \%$ przeszklenia elewacji południowej areny sportowej;

- usunięcie 50\% przeszklenia elewacji północnej areny sportowej;

- usunięcie $100 \%$ przeszklenia elewacji północnej areny sportowej.

Okres symulacji obejmuje czas od 15 maja do 15 września, kiedy w Polsce występuje ryzyko przegrzewania. Aktywność fizyczną użytkowników oraz izolacyjność odzieży przyjęto na podstawie normy [2]. Wartość aktywności metabolicznej, informującej o wielkości strumienia ciepła produkowanego przez organizm ludzki, przyjęto $300 \mathrm{~W} /$ osobę. Wielkość ta odnosi się do ciała dorosłego mężczyzny o powierzchni $1.8 \mathrm{~m}^{2}$, a dla kobiet i dzieci jest mnożona przez współczynniki korygujące: 0,85- kobieta i 0,75-dziecko. W próbach symulacyjnych założono wartość średnią współczynnika równą 0,9 . Izolacyjność odzieży przyjęto na poziomie 0,3 clo dla analizowanego okresu letniego. Ilość osób przebywających na arenie sportowej, uwzględniona w pracy badawczej, wynosiła 100 osób.

Hala sportowa posiada system wentylacji mechanicznej, który umożliwia odzyskanie części energii cieplnej. Wysokosprawny wymiennik ciepła (rekuparator) przejmuje dużą część ciepła odzyskaną z powietrza wywiewanego. Energia ta zostaje przekazana do strumienia powietrza nawiewanego z zewnatrz. Wymiennik charakteryzuje się wysoką sprawnością powyżej $80 \%$ i niskim zużyciem energii elektrycznej. Zimą powietrze zostaje w wymienniku podgrzane a latem - ochłodzone.

Wsparciem dla wentylacji mechanicznej, w badanym budynku, jest grawitacyjna wymiana powietrza. Zgodnie ze sposobem użytkowania obiektu, okna po stronie północnej są otwierane w momencie kiedy temperatura powietrza wewnątrz wynosi $24^{\circ} \mathrm{C}$. Powierzchnie szklone po stronie południowej uchylane są rano, od godziny 7.00-9.00 i po południu od 15-18.00. Przyjęto także, że minimalna temperatura powietrza zewnętrznego, przy której dopuszcza się wentylację grawitacyjną to $10^{\circ} \mathrm{C}$, a maksymalna wynosi $26^{\circ} \mathrm{C}$.

W symulacjach założono minimalną ilość świeżego powietrza równą $10 \mathrm{l} / \mathrm{s}-$ osobę. Według klasyfikacji normy PN-EN 13779 [3], odpowiada to średniej (medium) jakości powietrza i oznaczane jest jako IDA2 (Indoor Air Quality jakość powietrza wewnętrznego). 
Zacienienia wewnętrzne zamodelowano w postaci ruchomych rolet, wykorzystywanych do ochrony przeciwsłonecznej kiedy temperatura powietrza zewnętrznego osiągnie wartość $24^{\circ} \mathrm{C}$ w godzinach 9.00-15.00. Zewnętrzne łamacze światła o wysięgu $1 \mathrm{~m}$ są elementem stałym. Ich współczynnik zacienienia Fsh,gl wynosi w przybliżeniu 0,75 .

\section{Analiza symulacyjna obiektu}

Maksymalne oraz średnie wartości podstawowcyh parametrów środowiskowych dla całego okresu analizy zawiera tabela 1. Obliczono także odchylenie standardowe, obrazujące rozrzut wyników w stosunku do wartości średniej. Dla czteromięsiecznego okresu analizy, wskaźnik komfortu cieplnego przewidywanej oceny średniej wypada korzystnie ponieważ średnia jego wartość wynosi 0,43 i mieści się $\mathrm{W}$ przedziale Fangera [4]. Najwyższa temperatura powietrza wewnętrznego wyniosła $29^{\circ} \mathrm{C}$, a chwilowy wskaźnik komfortu cieplnego PMV przekroczył, dopuszczalną dla klimatu umiarkowa-nego, granicę równą 2,0. Miało to miejsce dnia 07.06. ok godziny 16.00 , kiedy okna po stronie południowej były uchylone, a rolety zwinięte. Wpływ osłon przeciwsłonecznych jest podstawą oddzielnej analizy, ale warto wspomnieć o tym fakcie także i w tym przypadku.

Tabela 1. Miary statystyczne podstawowych parametrów środowiskowych dla całego okresu analizy wariantu podstawowego

Table 1. Statistical measures of primary environmental parameters for measurements carried out for the whole period of the analysis of the basic variant

\begin{tabular}{|c|c|c|c|c|c|c|}
\hline & 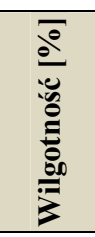 & 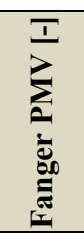 & 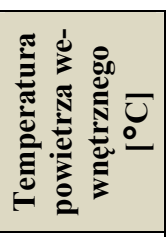 & 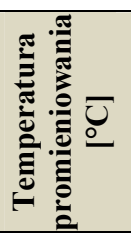 & 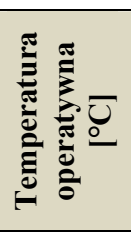 & 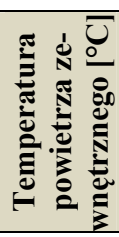 \\
\hline Max & 86,95 & 2,04 & 29,41 & 26,41 & 27,76 & 32,83 \\
\hline $\begin{array}{l}\text { Średnia aryt- } \\
\text { metyczna }\end{array}$ & 64,04 & 0,43 & 19,61 & 20,45 & 20,03 & 17,02 \\
\hline \begin{tabular}{|l|} 
Odchylenie \\
standardowe
\end{tabular} & 9,68 & 0,52 & 2,85 & 2,22 & 2,48 & 4,78 \\
\hline
\end{tabular}

Przez wzgląd na dużą rozpiętość danych pomiarowych, odrzucono wartości skrajne, a do szczegółowej analizy przyjęto okres 8 dni, od 15.08 do 22.08 . Patrząc pod kątem ryzyka przegrzewania, warunki środowiskowe wewnatrz były nieodpowiednie oraz stałe przez dłuższy czas. Maksymalne temperatury powietrza wewnętrznego przekraczały wartość $29^{\circ} \mathrm{C}$, co przedstawiono na rysunku 2 . 


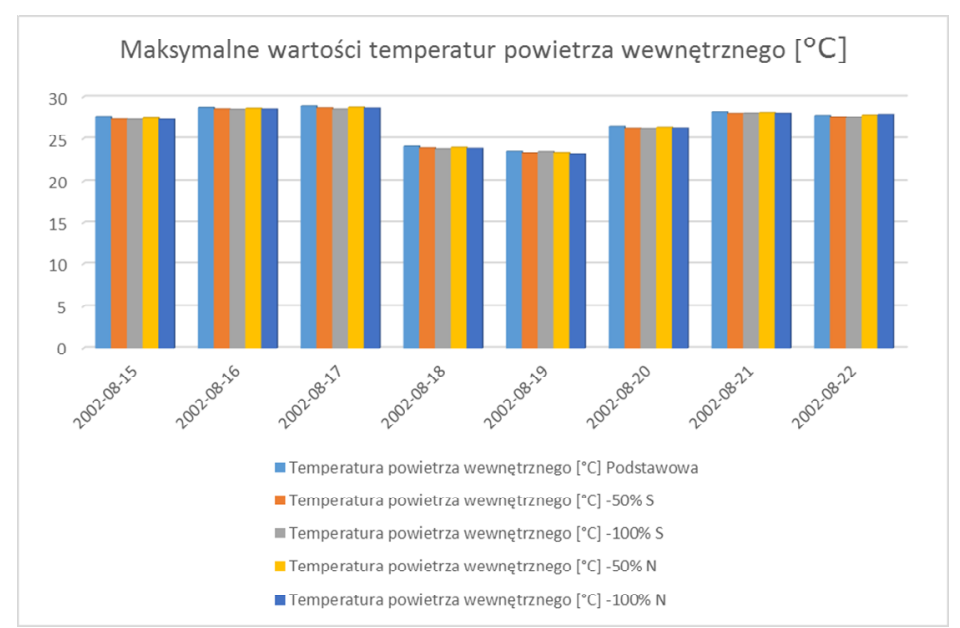

Rys. 2. Rozkład temperatury w hali dla wybranego okresu analizy

Fig. 2. Temperature distribution in hall for chosen analyze period

Rozkład temperatury powietrza wewnętrznego hali, (rysunku 2), obrazuje bardzo niewielkie różnice $\mathrm{w}$ wartościach maksymalnych dla poszczególnych wariantów symulacji. Na podstawie otrzymanych wyników można jednak zauważyć, że rozwiązanie zastosowane w projekcie skutkuje najwyższymi temperaturami, najmniejsze wartości otrzymuje się po zredukowaniu powierzchni przeszkleń po stronie południowej.

W rozpatrywanym dokładniej okresie ośmiodniowym, dobowa, maksymalna wartość wskaźnika przewidywanej oceny średniej zawierała się w przedziale 1,11 - 1,99. Wartości graniczne nie mieszczą się w strefie komfortu cieplnego Fangera [4], którą ograniczają wyznaczniki $-0,5-+0,5$. Dla każdego przyjętego wariantu symulacji, w badanym obiekcie sportowym występuje dyskomfort, który w różny sposób może wpływać na samopoczucie użytkowników. Wpływ wielkości i rozmieszczenia okien na mikroklimat wewnątrz hali, w zależności od usytuowania ściany względem strony świata, przedstawiono na rysunku 3. 


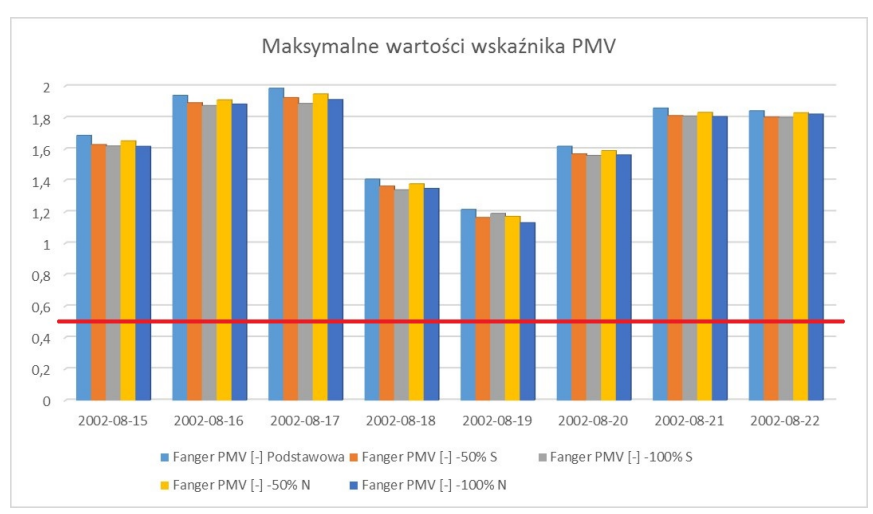

Rys. 3. Rozkład wskaźnika PMV dla wybranego okresu analizy

Fig. 3. PMV factor values for chosen analyze period

Wariant wyjściowy, zgodny z założeniami dokumentacji projektowej, zawiera najwyższe wartości wskaźnika PMV. Największa wartość wskaźnika przewidywanej oceny średniej, wynosząca 1,99, wypada dnia 17.08. o godzinie 16.00. Symulację, obrazującą pozycję słońca nad badaną halą dla tego przypad$\mathrm{ku}$, zobrazowano na rysunku 4. Elewacja południowa poddana jest intensywnemu działaniu promieni słonecznych przez większą część dnia. W konsekwencji tego następuje kumulacja energii cieplnej wewnątrz, co skutkuje wzrostem zapotrzebowania na chłodzenie.



Rys. 4. Rozkład zacienienia w dniu 17.08 o godzinie 16.00

Fig. 4. Distribution of shading on 17.08 at 16.00

Podobnie, jak to miało miejsce w przypadku analizy temperatury powietrza wewnętrznego, różnice w poszczególnych wartościach wskaźnika komfortu są niewielkie. Wariant, w którym zredukowano powierzchnie przezroczyste na elewacji południowej o 100\% wykazał najmniejszą wartość wskaźnika przewidywanej oceny średniej i wyniosła ona 1,89. Szklenie na elewacji północnej ma 
mniejszy wpływ, w porównaniu z południową, na obniżenie zysków od promieniowania słonecznego. Zadaniem okien po stronie północnej jest przede wszystkim zapewnienie naturalnego oświetlenie oraz wykorzystanie ich do nocnego przewietrzania, a nie ochrona przed przegrzewaniem.

Tabela 2. Miary statystyczne wartości wskaźnika przewidywanej oceny średniej PMV

Table 2. Statistic measures of PMV values

\begin{tabular}{|l|c|c|c|c|c|}
\cline { 2 - 6 } \multicolumn{1}{c|}{} & Podstawowa & $\mathbf{- 5 0 \% ~ S ~}$ & $\mathbf{- 1 0 0 \% ~ S}$ & $\mathbf{- 5 0 \%} \mathbf{~ N}$ & $\mathbf{- 1 0 0 \%} \mathbf{~ N}$ \\
\hline Max & $\mathbf{1 , 9 9}$ & $\mathbf{1 , 9 3}$ & $\mathbf{1 , 8 9}$ & $\mathbf{1 , 9 5}$ & $\mathbf{1 , 9 1}$ \\
\hline Wartość średnia & 1,25 & 1,20 & 1,19 & 1,22 & 1,19 \\
\hline Odchylenie standardowe & 0,36 & 0,35 & 0,35 & 0,36 & 0,37 \\
\hline
\end{tabular}

Rozpatrując otrzymane wyniki, mimo małych różnic, potwierdza się ogólne przeświadczenie, że to właśnie południowe elewacje szklone przede wszystkim wpływają na komfort termiczny. Świadome projektowanie powinno uwzględniać optymalną ilość przeszklenia na każdej elewacji, ze szczególnym zwróceniem uwagi na przegrody po stronie południowej. W celu obniżenia wartości wskaźnika przewidywanej oceny średniej dla analizowanego przypadku hali, można byłoby zastosować bardziej skuteczne osłony zewnętrzne, blokujące migrację promieniowania. W hali zamontowane są zewnętrzne łamacze światła, ale o stałych lamelach. Można byłoby zastosować ruchome osłony, umożliwiające regulację kąta ustawienia lamel, w zależności od położenia słońca.

\section{Podsumowanie wyników}

Przeprowadzone analizy dają jedynie wstępny pogląd wpływu doboru stopnia przeszklenia danej elewacji na mikroklimat wnętrza. W obowiązujących warunkach technicznych nie ma wymagań dotyczących ilości powierzchni szklonych w zależności od orientacji. Duże ilości promieniowania słonecznego przenikającego przez spore powierzchnie przezroczyste po stronie południowej, doprowadzają do wytworzenia niekorzystnych dla człowieka, warunków środowiska. Zastosowany w budynku system ochrony przed nadmiernymi zyskami słonecznymi, w postaci łamaczy zewnętrznych oraz rolet nie jest w stanie ochronić użytkowników hali przed dyskomfortem. Wzmożone przegrzewanie i związane z tym zwiększenie temperatury wnętrza, wysokie wskaźniki PMV, mogą być przyczyną obniżenia zdolności koncentracji i aktywności życiowcyh użytkowników obiektu. Jeżeli nie ma ścisłej korelacji pomiędzy szeregiem rozwiązań ograniczających przegrzewanie pomieszczeń, nie jest możliwe utrzymanie komfortu cieplnego w okresie letnim. 


\title{
Literatura
}

[1] Rozporządzenie Ministra Infrastruktury z dnia 12 kwietnia 2002 r. w sprawie warunków technicznych, jakim powinny odpowiadać budynki i ich usytuowanie, Dz.U. $2002 \mathrm{nr} 75$ poz. 690.

[2] PN-EN ISO 7730:2006, Ergonomia środowiska termicznego. Analityczne wyznaczanie i interpretacja komfortu termicznego z zastosowaniem obliczania wskaźników PMV i PPD oraz kryteriów lokalnego komfortu termicznego.

[3] PN-EN 13779:2008, Wentylacja budynków niemieszkalnych - Wymagania dotyczące właściwości instalacji wentylacji i klimatyzacji.

[4] Fanger P.O., Komfort cieplny, Arkady, Warszawa, 1974.

\section{ANALYSIS OF THE EFFECTS OF THE DEPLOYMENT OF PARTITIONS TRANSPARENT ON MICROCLIMATE IN PUBLIC PASSIVE BUILDING}

\begin{abstract}
S u m m a r y
The publication contains informations concerned to the impact of the transparent dividers deployment on the microclimate of the passive building. Five simulations were conducted allowing to qualify how much location of the windows is able to alter environmental conditions in the interior of the analysed room and it's influence on the limitation of overheating in summer. Windows on the south and northern elevation were removed about $50 \%$ and $100 \%$. In the simulations another possibilities connected with minimization of an excessive solar profits were not taken into account such as the kind of applied sun protections, night airing, the influence of the thermal mass or also the control of moisture and the movement of the air. Becouse of the narrow range of analysis, divergences in results are not essential but however they allow to make preliminary conclusions. South glazed elevations first of all cause influence on the temperature values of the internal air and either on the index of the foreseen avarage rate. The variant in which transparent surfaces were reduced on the south elevation about $100 \%$ showed the the smallest value of the foreseen average rate. The large quantities of the sunny radiation, penetrating through large transparent surfaces from the south side, are the discomfort reason. Northern windows in confrontation with the south elevation contribute to a lesser extent the lowering of solar profits. Projecting of glazing can't be overdone in both sides. Large surfaces can be the reason of the warmth losses in the winter but either the cause of overheating in the summer. Assuring the proper microclimate in the given environment guarantees the efficiency of executed tasks as well as health of the users and that is why it should be the key matter in projecting.
\end{abstract}

Keywords: thermal comfort, PMV, overheating, glazing

Przestano do redakcji: 21.05.2016 $r$.

Przyjęto do druku: $15.12 .2017 \mathrm{r}$. 